\title{
Single nucleotide polymorphisms in toll-like receptor genes and case- control association studies with bovine tuberculosis
}

Ashish Bhaladhare, Deepak Sharma, Amit Kumar, Arvind Sonwane, Anuj Chauhan, Ranvir Singh, Pushpendra Kumar, Ramji Yadav, Mohd Baqir, Bharat Bhushan and Om Prakash

Division of Animal Genetics, Indian Veterinary Research Institute, Izatnagar, Uttar Pradesh, India. Corresponding author: Anuj Chauhan, e-mail: anuj_vet99@rediffmail.com,

AB: abhaladhare@gmail.com, DS: anuj_vet99@rediffmail.com, AK: vetamitchandan07@gmail.com, AS: arvind2002@gmail.com, RS: rvsingh.icar@gmail.com, PK: pushpendra64@gmail.com, RY: drramjivet@gmail.com, MB: drbaqirvet@gmail.com, BB: bbhushan ivri2003@yahoo.co.in, OP: dromprakash0511@gmail.com Received: 06-10-2015, Accepted: 21-03-2016, Published online: 09-05-2016

doi: 10.14202/vetworld.2016.458-464 How to cite this article: Bhaladhare A, Sharma D, Kumar A, Sonwane A, Chauhan A, Singh R, Kumar P, Yadav R, Baqir M, Bhushan B, Prakash O (2016) Single nucleotide polymorphisms in toll-like receptor genes and case-control association studies with bovine tuberculosis, Veterinary World, 9(5): 458-464.

\begin{abstract}
Aim: Toll-like receptor 2 (TLR2) and TLR4 genes play critical roles in host recognition of Mycobacterium bovis infection and initiation of innate and adaptive immune response. The present study was aimed at exploring the association of seven single nucleotide polymorphisms (SNPs) in TLR2 and TLR4 genes with susceptibility/resistance against bovine tuberculosis (bTB) infection in cattle.
\end{abstract}

Materials and Methods: A case-control resource population of 35 positive and 45 negative animals was developed after screening with single intradermal tuberculin test for bTB. Resource population was screened for SNPs in TLR2 and TLR4 genes using polymerase chain reaction-restriction fragment length polymorphism. The PROC LOGISTIC procedure of SAS 9.3 was used to find an association of allelic and genotypic frequencies with bTB.

Results: In TLR2 gene, two of SNPs under study (rs55617172 and rs68268253) revealed polymorphism while in the case of TLR4 gene all four SNPs under investigation (rs8193041, rs207836014, rs8193060, and rs8193069) were found to be polymorphic in case-control population. SNP locus rs55617172 in TLR2 gene was found significantly (p<0.01) associated with susceptibility/resistance to TB in cattle.

Conclusion: These findings indicate the presence of SNPs in TLR2 and TLR4 genes in our resource population. Upon validation in independent, large resource population and following biological characterization, SNP rs55617172 can be incorporated in marker panel for selection of animals with greater resistance to bTB.

Keywords: bovine tuberculosis, immune response, resistance, single nucleotide polymorphisms, toll-like receptors

\section{Introduction}

Bovine tuberculosis(bTB) is a chronic debilitating infectious disease of cattle caused by Mycobacterium bovis. In addition to being an important pathogen of cattle, the host range of $M$. bovis has been reported to include humans, non-human primates, goats, pigs, buffalo, badgers, possums, deer, and bison $[1,2]$. bTB has been reported in almost every country of the world but is endemic in Africa and Indian subcontinent [3]. It costs estimated $\$ 3$ billion annually in global agricultural losses [4] and is the fourth most important livestock disease worldwide [3]. A loss of 10-25\% in milk production efficiency has been reported in TB-infected animals $[5,6]$.

M. bovis infection has a chronic progression where pathogenesis begins with bacterial entry to host lungs by inhalation and bacteria phagocytosis by

Copyright: Bhaladhare, et al. Open Access. This article is distributed under the terms of the Creative Commons Attribution 4.0 International License (http://creativecommons.org/licenses/ by/4.0/), which permits unrestricted use, distribution, and reproduction in any medium, provided you give appropriate credit to the original author(s) and the source, provide a link to the Creative Commons license, and indicate if changes were made. The Creative Commons Public Domain Dedication waiver (http:// creativecommons.org/publicdomain/zero/1.0/) applies to the data made available in this article, unless otherwise stated. alveolar macrophages. When disease develops over a period with incubation period ranging from several weeks to months, the associated granulomatous pathological changes are seen mainly in the lower and upper respiratory tract along with apparent clinical symptoms [7]. Thus, cattle may become infectious long before they exhibit clinical signs or lesions. Consequently, the mainstay of TB control in cattle lies in the early detection and removal of infected animals. Currently, no effective vaccine exists for bTB and treatment regimen available is not cost effective and generally not recommended. Moreover, eradication of the disease by slaughtering of affected animals is also difficult because of the socio-economic condition of farmers and the social customs or religious taboos [8]. Given the difficulties in eradicating bTB by conventional measures, improving genetic resistance to diseases among livestock populations could be an effective alternate strategy as the genetic gain is cumulative and permanent. Genetic variation in susceptibility to bTB has been observed in cattle. Differences in susceptibility to bTB at the level of the genus have been reported by Ameni et al. [9], indicating that Bos indicus cattle are more resistant than Bos taurus. Significant heritability has been reported for 
susceptibility to bTB in Holstein cattle in the UK [10] and in the Republic of Ireland [11].

Candidate gene approach can serve as a useful tool in identifying resistant superior genotypes for the production of the new resistant animal population [12]. Toll-like receptor 2 (TLR2) and TLR4 genes codes for molecules that are localized on the cell surface and recognize mycobacterial membrane components [13]. They recruit a specific set of adaptor molecules such as MyD88 and TRIF and activate MyD88-dependent and TRIF-dependent signaling pathways that lead to the secretion of inflammatory cytokines, type I interferon (IFN), chemokines, and antimicrobial peptides [14]. These responses cause recruitment of neutrophils, activation of macrophages, and induction of IFNstimulated genes, resulting in the direct killing of the infected mycobacterial pathogens and the induction of adaptive immunity [15]. TLR 2 and TLR 4 genes are thus promising candidates for exploring the association with susceptibility/resistance to bTB. Association of TLR2 polymorphism with TB has been reported in human [16-18], and in the case of Cattle, SNPs in TLR2 and TLR4 genes have been associated with susceptibility to paratuberculosis infection $[19,20]$. Polymorphisms have been reported within the TLR 2 and TLR4 genes in cattle [21,22]; however, reports of marker level association studies with bTB in cattle are lacking, especially indigenous breeds that could be used for selection and breeding of resistant/tolerant animals. Therefore, the objectives of this study were to genotype a resource population tested for bTB infection and to evaluate the association of seven single nucleotide polymorphisms (SNPs) in the TLR2 and TLR4 genes for susceptibility/resistance to bTB in cattle.

\section{Materials and Methods}

\section{Ethical approval}

The experiment was prior approved by the Animal Ethics Committee of the Institute constituted as per the article number 13 of the CPCSEA rules laid down by Government of India and conducted following the code of ethics for animal experimentation.

\section{Development of case-control population}

For the current investigation, resource population comprised 245 cattle including Indigenous (Koshi, Sahiwal, Gir)/Non-descript and crossbred from Shri Mataji Gaushala, Barsana. All animals were maintained under similar feeding and managemental practices and had an equal opportunity of infection. Animals were screened for the presence of bTB by Single intradermal tuberculin test, wherein increase in thickness of skin after $72 \mathrm{~h}$ of intradermal injection of tuberculin antigen was noted to develop case (tuberculin positive) and Control (tuberculin negative) resource panel. An intradermal inoculation of $0.1 \mathrm{ml}$ of tuberculin PPD antigen on neck region was carried out. The skin thickness was measured with vernier calipers before and $72 \mathrm{~h}$ after inoculation. Based on thickness, cattle were classified into three groups: Those showed marked swelling and skin thickness more than $4 \mathrm{~mm}$ (positive), skin thickness $<4 \mathrm{~mm}$ and $>2 \mathrm{~mm}$ (inconclusive), and no reaction $>2 \mathrm{~mm}$ (negative). The inconclusive animals were not included in the present investigation. A case and control resource panel of 35 positive and 45 negative animals was developed.

\section{Sample collection and isolation of genomic DNA}

From each of case and control animals, $5 \mathrm{ml}$ of blood was collected from a jugular vein in tubes containing $2.7 \%$ EDTA and stored at $-20^{\circ} \mathrm{C}$. DNA was isolated from whole blood using Promega Wizard ${ }^{\circledR}$ Genomic DNA Purification Kit as per recommended protocols. The DNA concentration was determined using Qubit Fluorometer. DNA quality was also assessed by $1 \%$ submarine agarose gel electrophoresis. $1 \mu \mathrm{l}$ of genomic DNA was resolved on $1 \%$ agarose gel stained with ethidium bromide or SYBR ${ }^{\circledR}$ Safe DNA gel stain, and quantification was made by comparing the intensity of the band with the intensity of a known quantity of lambda DNA. Only thick DNA band and without smearing were chosen for further processing.

\section{Genotyping of SNPs}

Primers for the 7 SNPs in TLR2 (rs55617172, rs43706434, and rs68268253) and TLR4 (rs8193041, rs207836014, rs8193060, and rs8193069) genes were designed using OligoAnalyzer (Integrated DNA Technology software) software for amplification of the loci. The detail of primers and restriction enzymes are being presented in Table-1. Concerned amplicons were amplified under the optimized polymerase chain reaction (PCR) condition. The PCR reaction was carried out in $25 \mu \mathrm{l}$ volume which included $1 \mu \mathrm{L}$ of each primer (forward and reverse), $1.5 \mu \mathrm{L} \mathrm{MgCl}_{2}$, $5 \mu \mathrm{l}$ buffer, $0.2 \mu \mathrm{L}$ dNTPs, $0.125-0.25 \mu \mathrm{l}$ Taq polymerase, $1 \mu 1$ genomic DNA, and Nuclease-free water $15.05-15.175 \mu 1$. The cycling program used for amplification having following steps: Initial denaturation $\left(94^{\circ} \mathrm{C}\right.$ for $\left.4 \mathrm{~min}\right)$, followed by 35 cycles of $30 \mathrm{~s}$ at $94^{\circ} \mathrm{C}, 30 \mathrm{~s}$ at annealing temperature (Table-1), $30 \mathrm{~s}$ at $72^{\circ} \mathrm{C}$, and final extension of $5 \mathrm{~min}$ at $72^{\circ} \mathrm{C}$. The PCR products were resolved in $2.4 \%$ agarose gel and visualized under UV light after staining with ethidium bromide. Restriction digestion was carried out in $25 \mu \mathrm{L}$ reaction volume which included $20 \mu \mathrm{L}$ of PCR product, $1.5 \mathrm{U}$ of restriction enzyme, $2.5 \mu \mathrm{L}$ of $10 \times$ buffer and NFW to make the volume up to $25 \mu \mathrm{L}$ and incubated at recommended temperature as prescribed by the manufacturer for $16 \mathrm{~h}$. The restriction enzyme digestion was made at the optimized conditions and the restriction digested products were resolved in $3.5 \%$ agarose gel and visualized under UV light after staining with ethidium bromide. Mass genotyping of all case-control resource population for all 7 SNPs was done using PCR-restriction fragment length polymorphism (PCR-RFLP). 
Table-1: SNPs with their primers and restriction enzymes.

\begin{tabular}{|c|c|c|c|c|c|c|c|c|}
\hline SNP id & Gene & SNP & Position & Primer sequence $\left(5^{\prime}-3^{\prime}\right)$ & $\begin{array}{c}\text { Annealing } \\
\text { temperature } \\
\left({ }^{\circ} \mathrm{C}\right)\end{array}$ & $\begin{array}{l}\text { Restriction } \\
\text { enzyme }\end{array}$ & $\begin{array}{l}\text { Amplicon } \\
\text { size (bp) }\end{array}$ & $\begin{array}{l}\text { Fragment } \\
\text { size (bp) }\end{array}$ \\
\hline rs55617172 & TLR2 & $\mathrm{G} / \mathrm{T}$ & +385 & $\begin{array}{l}\text { TTAAACTCCATCCСCTCTGG } \\
\text { TAAAGGGACCTGAACCAGG }\end{array}$ & 59.2 & EcoRV & 245 & 63,182 \\
\hline rs43706434 & TLR2 & $\mathrm{G} / \mathrm{A}$ & +651 & $\begin{array}{l}\text { GAACCTGAAGACTCTGAGG } \\
\text { CTGATCTCAAGCTCCTCAAG }\end{array}$ & 54.0 & PstI & 318 & 224,94 \\
\hline rs68268253 & TLR2 & $\mathrm{G} / \mathrm{T}$ & +1141 & $\begin{array}{l}\text { ACCAAGGTTTGAAGGAAGGG } \\
\text { TGATGACTGTACCCATGATGG }\end{array}$ & 56.8 & BsaAI & 327 & 235,92 \\
\hline rs8193041 & TLR4 & $\mathrm{C} / \mathrm{T}$ & +480 & $\begin{array}{l}\text { CGTAACCCAGCACTGCTTTG } \\
\text { GCCTGTTAATGCCCTGTAACC }\end{array}$ & 58.5 & BstUI & 405 & 159,246 \\
\hline rs207836014 & TLR4 & $\mathrm{C} / \mathrm{T}$ & +869 & $\begin{array}{l}\text { CACCTCTCCACCTTGATACTG } \\
\text { CTTCGCAGAGTCAATCCATTG }\end{array}$ & 56.5 & HaeIII & 398 & 92,306 \\
\hline rs8193060 & TLR4 & $\mathrm{C} / \mathrm{T}$ & +2126 & $\begin{array}{l}\text { GCTTAGTCAGTCTGCAAACC } \\
\text { CACTGCAGGAAACTCTGATG }\end{array}$ & 55.8 & ApeKI & 373 & 247,126 \\
\hline rs8193069 & TLR4 & $\mathrm{C} / \mathrm{T}$ & \pm 2491 & $\begin{array}{l}\text { GGGTCCTAGTCTACAAGTTC } \\
\text { ACGATGAAGATGATGCCAG }\end{array}$ & 53.9 & BsiHKAI & 367 & 75,292 \\
\hline
\end{tabular}

All above 7 SNPs were taken from SNP Database-dbSNP (http://www.ncbi.nlm.nih.gov/projects/SNP/). SNP=Single nucleotide polymorphisms, TLR=Toll-like receptor

\section{Statistical analysis}

Initially in univariate logistic regression analysis, the non-genetic factors such as age (two levels), sex (two levels), and breed (two levels) were fitted and found that none of these effects were significantly affecting the single intradermal tuberculin test result. The association between various allelic variants with bTB tolerance/susceptibility was worked out by suitable statistical techniques using different procedures of SAS 9.3. The PROC LOGISTIC procedure of SAS 9.3 was used to find the association of allelic and genotypic frequencies with bTB. The odds ratio (OR) of genotypes was calculated in affected population versus their contemporary genotypes. The PROC ALLELE procedure of the SAS 9.3 used for the estimation of polymorphism information content (PIC), Hardy-Weinberg equilibrium (HWE), and heterozygosity.

\section{Results and Discussion}

All non-genetic factors (breed, age, and sex) had non-significant $(\mathrm{p}<0.05)$ effect on the single intradermal tuberculin test for bTB. In the case of TLR2 gene, two of SNPs under study (rs55617172 and rs68268253) revealed polymorphism (Figures-1 and 2), whereas monomorphism was found in SNP rs43706434. While in the case of TLR4 gene all four SNPs under investigation (rs8193041, rs207836014, rs8193060, and rs8193069) were found to be polymorphic (Figures-3-6). These findings indicate the presence of these SNPs in our resource population. PIC ranged from 0.1186 (rs68268253) to 0.3744 (rs8193069) and revealing low to moderate polymorphism at the tested SNPs. The heterozygosity varied widely from a very low estimate of 0.024 (rs207836014) to 0.952 (rs8193069). Similarly, allelic diversity ranged from 0.023 (rs207836014) to 0.4989 (rs8193069). Except for SNP rs8193060 and rs207836014, all other SNPs in the population departed from HWE significantly

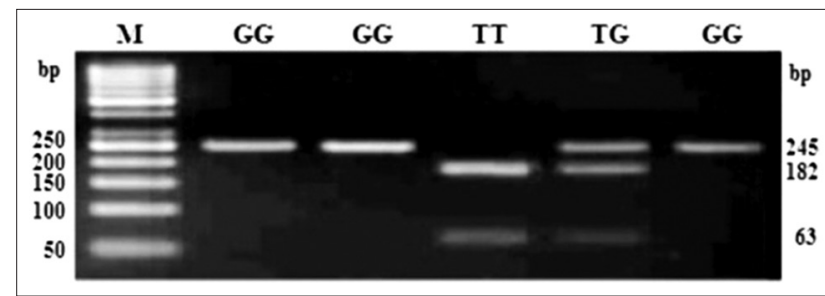

Figure-1: Polymerase chain reaction-restriction fragment length polymorphism profile of single nucleotide polymorphism rs55617172 in 3.5\% agarose gel. Lane M: 50 bp ladder.

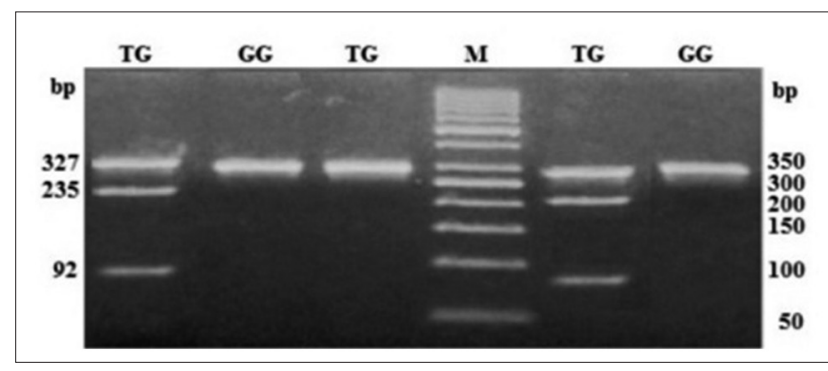

Figure-2: Polymerase chain reaction-restriction fragment length polymorphism profile of single nucleotide polymorphism rs68268253 in $3.5 \%$ agarose gel. Lane M: 50 bp ladder.

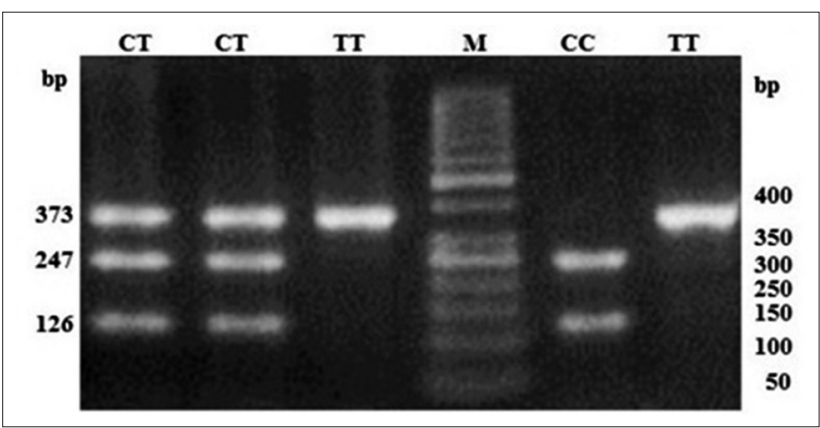

Figure-3: Polymerase chain reaction-restriction fragment length polymorphism profile of single nucleotide polymorphism rs8193060 in $3.5 \%$ agarose gel. Lane M: 50 bp ladder. 


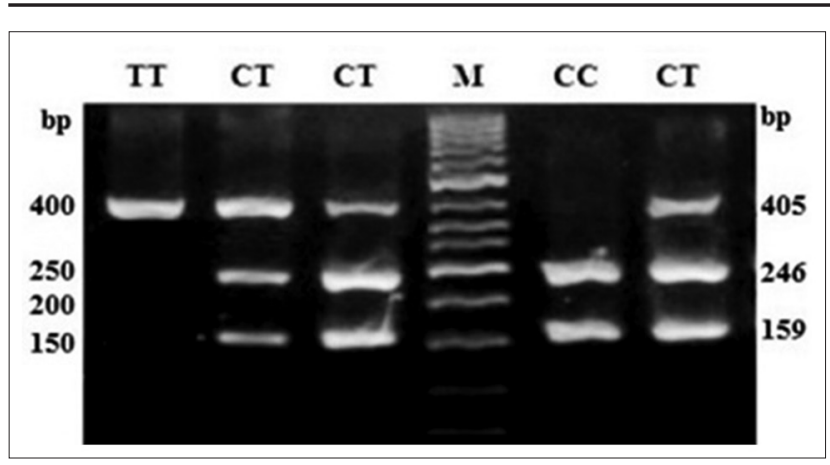

Figure-4: Polymerase chain reaction-restriction fragment length polymorphism profile of single nucleotide polymorphism rs8193041 in 3.5\% agarose gel. Lane M: 50 bp ladder.

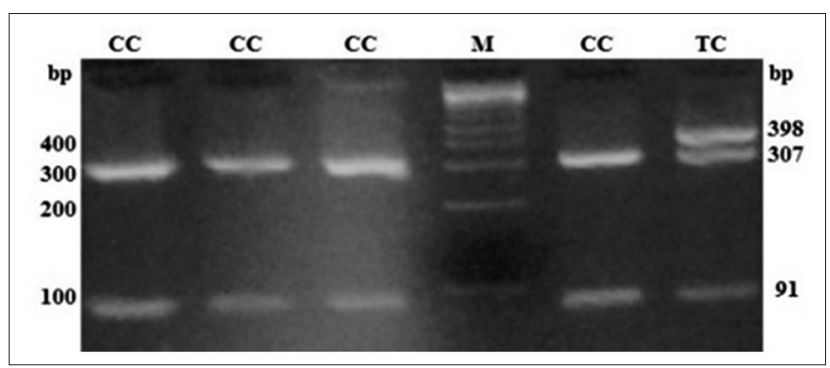

Figure-5: Polymerase chain reaction-restriction fragment length polymorphism profile of single nucleotide polymorphism rs207836014 in 3.5\% agarose gel. Lane M: 100 bp ladder.

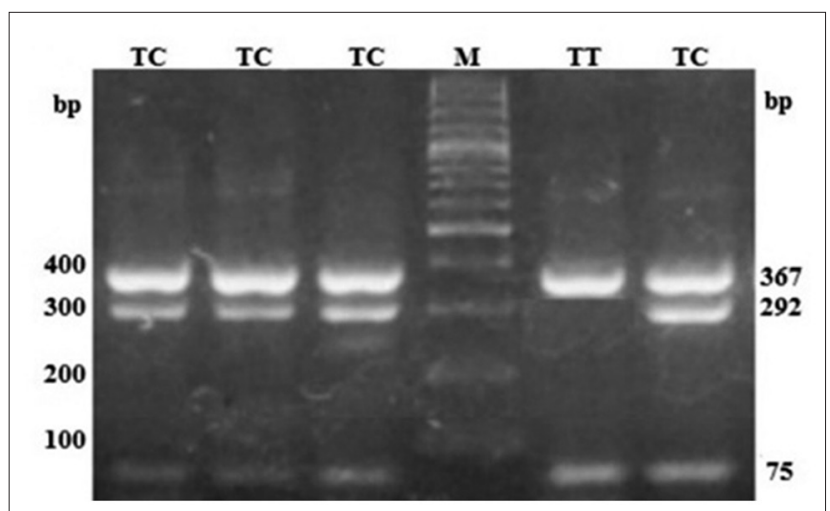

Figure-6: Polymerase chain reaction-restriction fragment length polymorphism profile of single nucleotide polymorphism rs8193069 in $3.5 \%$ agarose gel. Lane M: 100 bp ladder.

$(p<0.05)$. This significant departure from HWE may be due to non-static herd strength at the Gaushala. The allelic frequencies and the genotypic frequencies in case and control populations at different SNP loci and their effect on susceptibility to infection along with OR have been shown in Tables-2 and 3, respectively. For the polymorphic SNPs, PIC, heterozygosity, Allelic diversity and probabilities of being the population in HWE is presented in Table-4.

At SNP locus rs55617172, two alleles, i.e. $\mathrm{G}$ and $\mathrm{T}$ and three genotypes, i.e. GG (245 bp), TT (63 and 182 bp), and TG (245, 63, and 182 bp) were observed. The probability values showed that the genotype $(p<0.01)$ as well as allele $(p<0.01)$ had a significant effect on the occurrence of bTB. The OR of $G$ versus $T$ was 3.60 (1.47-8.81; 95\% confidence interval $[\mathrm{CI}])$, whereas OR of GG versus TT and TG versus TT was $2.88(0.52-16.14 ; 95 \% \mathrm{CI})$ and $0.42(0.05-$ $3.22 ; 95 \% \mathrm{CI}$ ), respectively (Tables-2 and 3). At SNP locus rs68268253, two alleles, i.e. $\mathrm{G}$ and $\mathrm{T}$ and two genotypes, i.e. GG (327 bp) and TG (327, 235, and $92 \mathrm{bp})$ were observed. The probability values showed that the genotype $(p=0.91)$ as well as allele $(p=0.91)$ had a non-significant effect on the occurrence of bTB. The OR of $\mathrm{G}$ versus $\mathrm{T}$ was $1.08(0.29-3.96 ; 95 \%$ $\mathrm{CI})$, whereas OR of GG versus TG was $1.08(0.28$ 4.16; 95\% CI), respectively (Tables-2 and 3). At SNP locus rs8193060, two alleles, i.e. $\mathrm{C}$ and $\mathrm{T}$ and three genotypes, i.e. CC $(247,126 \mathrm{bp}), \mathrm{TC}(373,247$, and $126 \mathrm{bp}$ ), and TT (373 bp) were observed. The probability values showed that the genotype $(\mathrm{p}=0.48)$ as well as allele $(\mathrm{p}=0.32)$ did not have any significant effect on the occurrence of bTB. The OR of C versus $\mathrm{T}$ was $0.67(0.31-1.46 ; 95 \% \mathrm{CI})$, whereas the OR of $\mathrm{CC}$ versus TT and TC versus TT was 0.77 (0.12-5.01; 95\% CI) and $0.55(0.2-1.48 ; 95 \% \mathrm{CI})$, respectively (Tables-2 and 3). At SNP locus rs8193041, two alleles, i.e. $\mathrm{C}$ and $\mathrm{T}$ and three genotypes, i.e. CC (159 and $246 \mathrm{bp}), \mathrm{TC}(405,159$, and $246 \mathrm{bp}$ ), and TT (405 bp) were observed. The probability values showed that the genotype $(\mathrm{p}=0.21)$ as well as allele $(\mathrm{p}=0.63)$ had not significant effect on the occurrence of bTB. The OR of $\mathrm{C}$ versus $\mathrm{T}$ was $1.16(0.62-2.19 ; 95 \% \mathrm{CI})$, whereas OR of CC versus TT and TC versus TT was $<0.01$ $(<0.01->999.99 ; 95 \% \mathrm{CI})$ and $<0.01(<0.01->999.99$; 95\% CI), respectively (Tables-2 and 3). At SNP locus rs207836014, two alleles, i.e. $\mathrm{C}$ and $\mathrm{T}$ and two genotypes, i.e. CC (91 and $307 \mathrm{bp}$ ) and TC $(398,91$, and $307 \mathrm{bp}$ ) were observed. The probability values showed that the genotype $(p=0.81)$ as well as allele $(p=0.76)$ had not significant effect on the occurrence of bTB. The OR of $\mathrm{C}$ versus $\mathrm{T}$ was $0.71(0.04-11.56$; $95 \% \mathrm{CI})$, whereas OR of CC versus TC was 0.71 (0.04-11.72; 95\% CI), respectively (Tables-2 and 3). At SNP locus rs8193069, two alleles, i.e. $\mathrm{C}$ and $\mathrm{T}$ and two genotypes, i.e. TC (367, 75 and $292 \mathrm{bp)}$ and TT (367 bp) were observed. The probability values showed that the genotype $(p=0.73)$ as well as allele $(p=0.92)$ had not significant effect on the occurrence of bTB. The OR of $\mathrm{C}$ versus $\mathrm{T}$ was $0.96(0.52-1.78 ; 95 \% \mathrm{CI})$, whereas OR of TC versus TT was $0.7(0.09-5.24 ; 95 \% \mathrm{CI})$, respectively (Tables-2 and 3). The linkage disequilibrium analysis revealed that the significantly linked loci/SNPs were TLR4-C2126T with TLR2-G1141T. All other loci/SNPs of the investigation were having non-significant LD suggested that there was no linkage between alleles of these loci.

Overall, out of seven SNPs explored in TLR2 and TLR4 genes for association with susceptibility/ resistance to bTB in our case: Control resource population rs55617172 in TLR2 gene showed a significant effect on susceptibility to bTB $(\mathrm{p}<0.01)$. The OR of GG versus TT (Table-3) revealed more susceptibility 
Table-2: Allelic frequency distribution of TLR genes and their association with bTB.

\begin{tabular}{|c|c|c|c|c|c|}
\hline \multirow[t]{2}{*}{ SNP } & \multirow[t]{2}{*}{ Allele } & \multicolumn{2}{|c|}{ Allele frequency } & \multirow[t]{2}{*}{ p value } & \multirow[t]{2}{*}{ OR $(95 \% \mathrm{CI})$} \\
\hline & & Case & Control & & \\
\hline \multirow[t]{2}{*}{ rs55617172 } & G & $60(0.857)$ & $70(0.714)$ & \multirow[t]{2}{*}{$<0.01$} & $3.60(1.47-8.81)$ \\
\hline & $\mathrm{T}$ & $10(0.143)$ & $28(0.286)$ & & 1 \\
\hline \multirow[t]{2}{*}{ rs68268253 } & G & $66(0.943)$ & $92(0.939)$ & \multirow[t]{2}{*}{0.91} & $1.08(0.29-3.96)$ \\
\hline & $\mathrm{T}$ & $4(0.057)$ & $6(0.0612)$ & & 1 \\
\hline \multirow[t]{2}{*}{ rs8193041 } & C & $44(0.629)$ & $58(0.592)$ & \multirow[t]{2}{*}{0.63} & $1.16(0.62-2.19)$ \\
\hline & $\mathrm{T}$ & $26(0.371)$ & $40(0.401)$ & & 1 \\
\hline \multirow[t]{2}{*}{ rs207836014 } & C & $69(0.986)$ & $97(0.990)$ & \multirow[t]{2}{*}{0.76} & $0.71(0.04-11.56)$ \\
\hline & $\mathrm{T}$ & $1(0.014)$ & $1(0.010)$ & & 1 \\
\hline \multirow[t]{2}{*}{ rs8193060 } & $\mathrm{C}$ & $12(0.171)$ & $23(0.235)$ & \multirow[t]{2}{*}{0.32} & $0.67(0.31-1.46)$ \\
\hline & $\mathrm{T}$ & $58(0.829)$ & $75(0.765)$ & & 1 \\
\hline \multirow[t]{2}{*}{ rs8193069 } & $\mathrm{C}$ & $33(0.471)$ & $47(0.480)$ & \multirow[t]{2}{*}{0.92} & $0.96(0.52-1.78)$ \\
\hline & $\mathrm{T}$ & $37(0.529)$ & $51(0.520)$ & & 1 \\
\hline
\end{tabular}

$\mathrm{SNP}=$ Single nucleotide polymorphisms, $\mathrm{TLR}=$ Toll-like receptor, $\mathrm{bTB}=$ Bovine tuberculosis, $\mathrm{OR}=$ Odds ratio, $\mathrm{CI}=$ Confidence interval

Table-3: Genotype frequency distribution of TLR genes and their association with bTB.

\begin{tabular}{|c|c|c|c|c|c|}
\hline \multirow[t]{2}{*}{ SNP } & \multirow[t]{2}{*}{ Genotype } & \multicolumn{2}{|c|}{ Genotype frequency } & \multirow[t]{2}{*}{ p value } & \multirow[t]{2}{*}{ OR (95\% CI) } \\
\hline & & Case & Control & & \\
\hline \multirow[t]{3}{*}{ rs55617172 } & GG & $27(0.772)$ & $26(0.531)$ & $<0.01$ & $2.88(0.52-16.14)$ \\
\hline & TG & $6(0.171)$ & $18(0.367)$ & & $0.42(0.05-3.22)$ \\
\hline & $\pi$ & $2(0.057)$ & $5(0.102)$ & & 1 \\
\hline \multirow[t]{2}{*}{ rs68268253 } & G/G & $31(0.886)$ & $43(0.878)$ & 0.91 & $1.08(0.28-4.16)$ \\
\hline & $\mathrm{G} / \mathrm{T}$ & $4(0.114)$ & $(0.122)$ & & 1 \\
\hline \multirow[t]{3}{*}{ rs8193041 } & $\mathrm{C} / \mathrm{C}$ & $10(0.286)$ & $9(0.184)$ & 0.21 & $<0.01(<0.01->999.99)$ \\
\hline & $\mathrm{C} / \mathrm{T}$ & $24(0.686)$ & $40(0.816)$ & & $<0.01(<0.01->999.99)$ \\
\hline & $\mathrm{T} / \mathrm{T}$ & $1(0.029)$ & 0 & & 1 \\
\hline \multirow[t]{2}{*}{ rs207836014 } & $\mathrm{C} / \mathrm{C}$ & $34(0.971)$ & $48(0.980)$ & 0.81 & $0.71(0.04-11.72)$ \\
\hline & $\mathrm{C} / \mathrm{T}$ & $1(0.029)$ & $1(0.020)$ & & 1 \\
\hline \multirow[t]{3}{*}{ rs8193060 } & $\mathrm{C} / \mathrm{C}$ & $2(0.057)$ & $3(0.061)$ & 0.48 & $0.77(0.12-5.01)$ \\
\hline & $\mathrm{C} / \mathrm{T}$ & $8(0.229)$ & $17(0.347)$ & & $0.55(0.2-1.48)$ \\
\hline & $\mathrm{T} / \mathrm{T}$ & $25(0.714)$ & $29(0.592)$ & & 1 \\
\hline \multirow[t]{2}{*}{ rs8193069 } & $\mathrm{C} / \mathrm{T}$ & $33(0.943)$ & $47(0.959)$ & 0.73 & $0.7(0.09-5.24)$ \\
\hline & $\mathrm{T} / \mathrm{T}$ & $2(0.052)$ & $2(0.041)$ & & 1 \\
\hline
\end{tabular}

$\mathrm{TLR}=$ Toll-like receptor, $\mathrm{bTB}=$ Bovine tuberculosis, $\mathrm{OR}=$ Odds ratio, $\mathrm{CI}=$ Confidence interval

Table-4: PIC, heterozygosity and HWE and probability distribution in total resource population of cattle.

\begin{tabular}{lcccc}
\hline SNP & PIC & Heterozygosity & Allelic diversity & HWE $\left(\chi^{2}\right)$ \\
\hline rs55617172 & 0.2755 & 0.2500 & 0.3299 & 0.0265 \\
rs68268253 & 0.1186 & 0.1190 & 0.1237 & $<0.0001$ \\
rs8193041 & 0.3633 & 0.7619 & 0.4770 & $<0.0001$ \\
rs207836014 & 0.0232 & 0.0238 & 0.0235 & 0.9121 \\
rs8193060 & 0.2755 & 0.2976 & 0.329 & 0.3703 \\
rs8193069 & 0.3744 & 0.9524 & 0.4989 & $<0.0001$ \\
\hline
\end{tabular}

PIC=Polymorphism information content, $\mathrm{HWE}=$ Hardy-Weinberg equilibrium

of GG genotype to bTB while the OR of TG genotype versus TT genotype suggested that TG genotypes are more resistant to bTB as compared to TT genotype. With regard to the effect of alleles, OR of $\mathrm{G}$ versus $\mathrm{T}$ allele (Table-2) suggested more susceptibility to bTB with $\mathrm{G}$ allele in comparison to $\mathrm{T}$ allele. In earlier studies, polymorphisms have been previously reported in TLR2 and TLR4 genes in cattle [21-24]. There is no report of the association of SNPs in TLR2 with the susceptibility to bTB. However, Zhang et al. [25] reported the association of TLR2-G385T with mastitis in cattle, wherein mean of genotype GG was reported significantly lower than those of genotype TT and
TG for somatic cell score. However, there are also several reports on the association of TLR2 polymorphism with bTB in human [16-18]. Though all the four SNPs studied for TLR4 gene showed their presence in our case, control population but the polymorphism at these loci was not found to be significantly ( $>0.05)$ associated with the susceptibility to bTB. Though TLR-4 have a specific role in immune response against bTB [26], the association of SNPs from TLR4 gene with susceptibility to bTB had not been reported in cattle. Since TLR4 have a key role in immunity against $M$. bovis thus more number of SNPs validations in a larger population may reveal 
some significant association of TLR4 SNPs with susceptibility of bTB.

\section{Conclusion}

Evidence shows that genetic factors might be important determinants in explaining individual variation in the outcome of exposure to $M$. bovis pathogen in cattle sharing similar environmental and managemental conditions. Candidate genes coding for proteins with very specific and unique roles in immune responses are potential strong candidates for investigating the genetic basis of bTB susceptibility/resistance. TLR2 and TLR4 genes codes for important molecules involved in modulation of both innate and adaptive immune response against bTB. In the present investigation, we raised the question whether polymorphisms of TLR2 or TLR4 are associated with the risk of bTB. Out of the 6 existent SNPs in TLR2 and TLR4 genes in the case-control population, rs55617172 locus was found significantly $(p<0.01)$ associated with susceptibility/resistance to TB in cattle. All the SNPs investigated were non-synonymous and suggested their functional role in the immune response against bTB. Additional validation in independent, large resource population and biological characterization are necessary before SNP can be incorporated in SNP panel for selection of animals with greater resistance to bTB. In addition, other SNPs of these concerned genes could be further exploited for association studies in cattle.

\section{Authors' Contributions}

$\mathrm{AB}$ : Research was done by this author as the part of his master's degree thesis dissertation; DS: Designed the study and supervised the research as major advisor; RY, MB, and OP: Worked and collaborated in the lab work and compilation of the results as well as the manuscript; AK, AS, and AC: Provided valuable suggestions regarding the design of the experiment and analysis of the data collected during research; PK, RS, and BB: Advised in all aspects of the work and shared lab facilities. All authors read and approved the final manuscript.

\section{Acknowledgments}

The authors are thankful to the Director of the Institute for providing necessary funding and facilities and personnel to carry out this work.

\section{Competing Interests}

The authors declare that they have no competing interests.

\section{References}

1. Thoen, C., LoBue, P. and De Kantor, I. (2006) The importance of Mycobacterium bovis as a zoonosis. Vet. Microbiol., 112(2-4): 339-345.

2. LoBue, P.A., Enarson, D.A. and Thoen, C.O. (2010) Tuberculosis in humans and animals: An overview. Int. J. Tuberc. Lung D., 14(9): 1075-1078.

3. Perry, B.D., Grace, D. and Sones, K. (2013) Current drivers and future directions of global livestock disease dynamics. P. Natl. Acad. Sci. USA., 110(52): 20871-20877.

4. Garnier, T., Eiglmeier, K., Camus, J.C., Medina, N., Mansoor, H., Pryor, M., Duthoy, S., Grondin, S., Lacroix, C., Monsempe, C., Simon, S., Harris, B., Atkin, R., Doggett, J., Mayes, R., Keating, L., Wheeler, P.R., Parkhill, J., Barrell, B.G., Cole, S.T., Gordon, S.V. and Hewinson, R.G. (2003) The complete genome sequence of Mycobacterium bovis. P. Natl. Acad. Sci. USA., 100(13): 7877-7882.

5. Boland, F., Kelly, G.E., Good, M. and More, S.J. (2010) Bovine tuberculosis and milk production in infected dairy herds in Ireland. Prev. Vet. Med., 93(2-3): 153-161.

6. Dhama, K., Chakraborty, S., Kapoor, S., Tiwari, R., Kumar, A., Deb, R., Rajagunalan, S., Singh, R., Vora, K. and Natesan, S. (2013) One world, one health - Veterinary perspectives. Adv. Anim. Vet. Sci., 1(1): 5-13.

7. Neill, S., Bryson, D. and Pollock, J. (2001) Pathogenesis of tuberculosis in cattle. Tuberculosis, 81: 79-86.

8. Verma, A.K., Tiwari, R., Chakraborty, S., Neha, Saminathan, M., Dhama, K. and Singh, S.V. (2014) Insights into bovine tuberculosis (bTB), various approaches for its diagnosis, control and its public health concerns: An update. Asian J. Anim. Vet. Adv., 9: 323-344.

9. Ameni, G., Aseffa, A., Engers, H., Young, D., Gordon, S., Hewinson, G. and Vordermeier, M. (2007) High prevalence and increased severity of pathology of bovine tuberculosis in Holsteins compared to zebu breeds under field cattle husbandry in central Ethiopia. Clin. Vac. Immunol., 14(10): 1356-1361.

10. Bermingham, M.L., More, S.J., Good, M., Cromie, A.R., Higgins, I.M., Brotherstone, S. and Berry, D.P. (2009) Genetics of tuberculosis in Irish Holstein-Friesian dairy herds. J. Dairy Sci., 92(7): 3447-3456.

11. Brotherstone, S., White, I.M.S., Coffey, M., Downs, S.H., Mitchell, A.P., Clfton-Hadley, R.S., More, S.J., Good, M. and Woolliams, J.A. (2010) Evidence of genetic resistance of cattle to infection with Mycobacterium bovis. J. Dairy Sci., 93: 1234-1242.

12. Bermingham, M.L., Bishop, S.C., Woolliams, J.A., PongWong, A.A.R., McBride, S.H., Ryder, J.J., Wright, D.M., Skuce, R.A., McDowell, S.W.J. and Glass, E.J. (2014) Genome-wide association study identifies novel loci associated with resistance to bovine tuberculosis. Heredity, 112: 543-551.

13. Akira, S., Takeda, K. and Kaisho, T. (2001) Toll-like receptors: Critical proteins linking innate and acquired immunity. Natl. Immunol., 2: 675-680.

14. Kawai, T. and Akira, S. (2010) The role of pattern-recognition receptors in innate immunity: Update on Toll-like receptors. Nat. Immunol., 11: 373-384.

15. Saiga, H., Shimada, Y. and Takeda, K. (2011) Innate immune effectors in mycobacterial infection. Clin. Dev. Immunol., 2011: 347594.

16. Ben-Ali, M., Barbouche, M.R., Bousnina, S., Chabbou, A. and Dellagi, K. (2004) Toll-like receptor 2 Arg677Trp polymorphism is associated with susceptibility to tuberculosis in Tunisian patients. Clin. Diagn. Lab. Immunol., 11(3): 625-626.

17. Sanchez, D., Rojas, M., Hernandez, I., Radzioch, D., Garcia, L.F. and Barrera, L.F. (2010) Role of TLR2and TLR4-mediated signaling in Mycobacterium tuberculosis - Induced macrophage death. Cell Immunol., 260: 128-136.

18. Velez, D.R., Wejse, C., Stryjewski, M.E., Abbate, E., Hulme, W.F., Myers, J.L., Estevan, R., Patillo, S.G., Olesen, R., Tacconelli, A., Sirugo, G., Gilbert, J.R., Hamilton, C.D. and Scott, W.K. (2010) Variants in toll-like receptors 2 and 9 influence susceptibility to pulmonary tuberculosis in Caucasians, African-Americans, and West Africans. Hum. Genet., 127(1): 65-73.

19. Koets, A., Santema, W., Mertens, H., Oostenrijk, D., Keestra, M., Overdijk, M., Labouriau, R., Franken, P., 
Frijters, A., Nielen, M. and Rutten, V. (2010) Susceptibility to paratuberculosis infection in cattle is associated with single nucleotide polymorphisms in Toll-like receptor 2 which modulate immune responses against Mycobacterium avium subspecies paratuberculosis. Prev. Vet. Med., 93(4): 305-315.

20. Sharma, B.S., Abo-Ismail, M.K., Schenkel, F.S., You, Q., Verschoor, C.P., Pant, S.D. and Karrow, N.A. (2015) Association of TLR4 polymorphisms with Mycobacterium avium subspecies paratuberculosis infection status in Canadian Holsteins. Anim. Genet., 46(5): 560-565.

21. Pant, S.D., Schenkel, F.S., Leyva-Baca, I., Sharma, B.S. and Karrow, N.A. (2008) Identification of polymorphisms in bovine TLR2 and CARD15, associations between CARD15 polymorphisms and milk somatic cell score in Canadian Holsteins, and functional relevance of SNP c.3020A $>$ T. Dev. Biol. (Basel)., 132: 247-253.

22. Mariotti, M., Williams, J.L., Dunner, S., Valentini, A. and
Pariset, L. (2009) Polymorphisms within the toll-like receptor (TLR)-2, -4, and -6 genes in cattle. Diversity, 1: 7-18.

23. Mucha, R., Bhide, M.R., Chakurkar, E.B., Novak, M. and Mikula, I. Sr. (2008) Toll-like receptors TLR1, TLR2 and TLR4 gene mutations and natural resistance to Mycobacterium avium subsp. paratuberculosis infection in cattle. Vet. Immunol. Immunop., 128(4): 381-388.

24. Wakchaure, S.R., Gupta, I.D., Verma, A., Rajesh, K.S. and Kumar, D. (2012) Study of toll-like receptors 4 (TLR4) gene in cattle: A review. Agric. Rev., 33(3): 220-225.

25. Zhang, L.P., Gan, Q.F., Ma, T.H., Li, H.D., Wang, X.P., Li, J.Y., Gao, X., Chen, J.B., Ren, H.Y. and Xu, S.Z. (2009) Toll-like receptor 2 gene polymorphism and its relationship with SCS in dairy cattle. Anim. Biotechnol., 20(3): 87-95.

26. Kawai, T. and Akira, S. (2011) Toll-like receptors and their crosstalk with other innate receptors in infection and immunity. Immunity, 34: 637-650.

$* * * * * * * *$ 